\title{
Commentary: Deformation Pattern of the Northern Sector of the Malta Escarpment (Offshore SE Sicily, Italy): Fault Dimension, Slip Prediction, and Seismotectonic Implications
}

\author{
Andrea Argnani * \\ ISMAR-CNR, Bologna, Italy
}

Keywords: Malta escarpment, active tectonics, extensional faults, seismic stratigraphy, ionian basin

\section{A Commentary on}

Deformation Pattern of the Northern Sector of the Malta Escarpment (Offshore SE Sicily, Italy): Fault Dimension, Slip Prediction, and Seismotectonic Implications

by Gambino, S., Barreca, G., Gross, F., Monaco, C., Krastel, S. and Gutscher, M.-A. (2021). Front.

OPEN ACCESS

Edited by:

Valerio Acocella,

Roma Tre University, Italy

Reviewed by:

Marco Neri,

National Institute of Geophysics and

Volcanology, Italy

*Correspondence:

Andrea Argnani

andrea.argnani@ismar.cnr.it

Specialty section:

This article was submitted to

Structural Geology and Tectonics,

a section of the journal

Frontiers in Earth Science

Received: 03 September 2021 Accepted: 04 October 2021

Published: 19 October 2021

Citation:

Argnani A (2021) Commentary: Deformation Pattern of the Northern

Sector of the Malta Escarpment

(Offshore SE Sicily, Italy): Fault

Dimension, Slip Prediction, and

Seismotectonic Implications.

Front. Earth Sci. 9:770364.

doi: 10.3389/feart.2021.770364

\section{INTRODUCTION}

With the aim to contribute to the understanding of the seismotectonics of SE Sicily, (Gambino et al., 2021) (GAMB hereafter) address the northern sector of the Malta Escarpment by studying a set of marine seismic profiles. They make use of both previously published profiles and some original data; the latter belong to a set of high resolution profiles that were acquired during a project not focussed on the Malta Escarpment. These new profiles are located in the northernmost sector of the Malta Escarpment, where its expression is poorly developed; they are very short and with little penetration and bring only a limited contribution to characterize the fault geometry along the Malta Escarpment. As a result, most of the work of GAMB seems based on a reanalysis of published data, in particular of one profile (CIR-01; (Gutscher et al., 2017)).

\section{DISCUSSION}

\section{Stratigraphy: The Aftermath of Uncertainties}

The seismic profiles analyzed by GAMB belong to different sets and have very different seismic characters and resolution, making seismic facies correlation pretty difficult, also because no tie lines are available. As a result, stratigraphic correlations are highly speculative and the ensuing uncertainties undermine the timing of the tectonic evolution envisaged by GAMB, as well as the age and rate of activity of tectonic structures.

GAMB claim that their PQ1 (Pliocene-early Pleistocene) and PQ2 (middle-late Pleistocene) units correlate with units PQb and PQa of (Camerlenghi et al., 2020), respectively. These units, however, cannot be traced physically from the deep Ionian basin, where they have been defined. The 

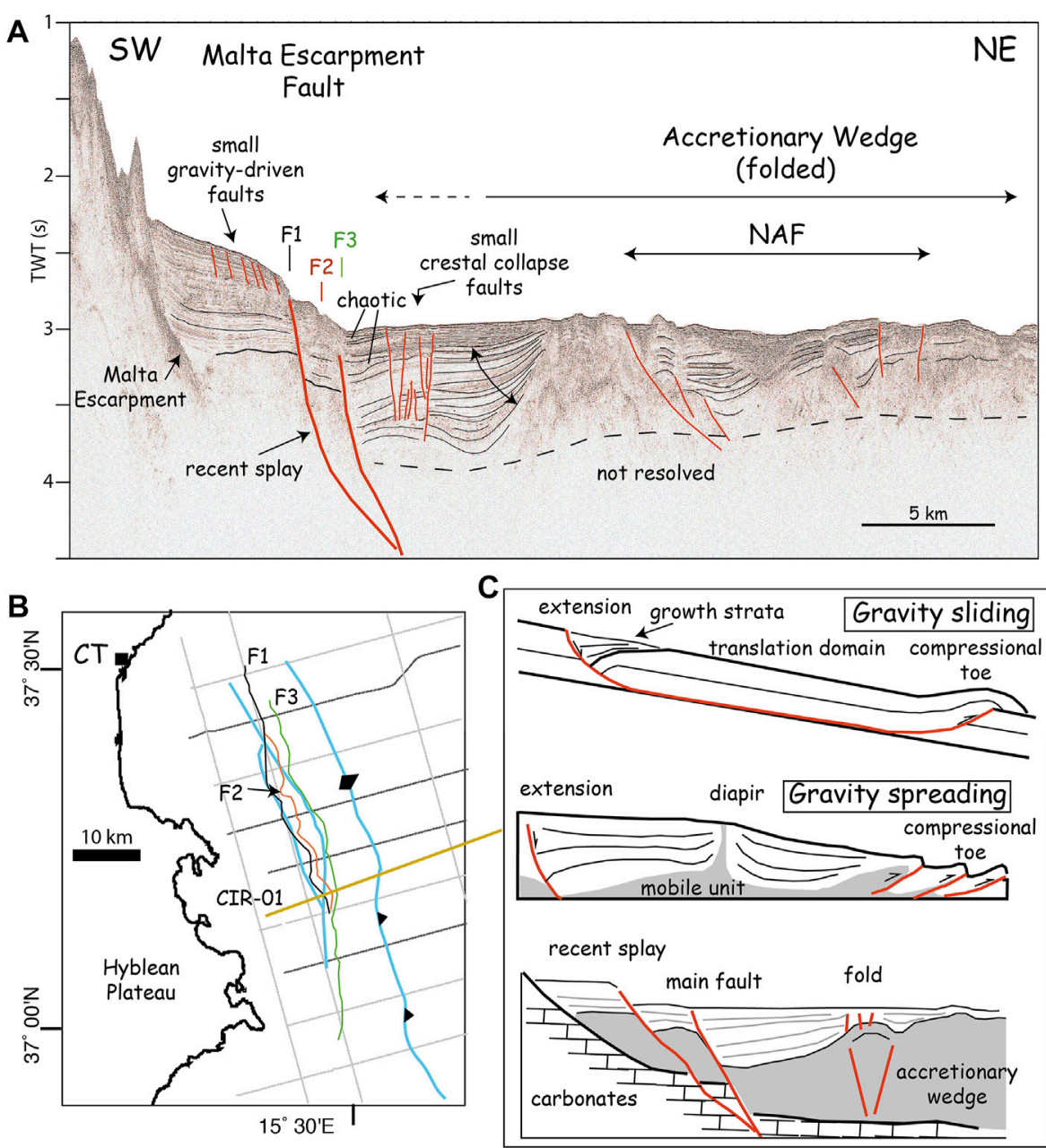

FIGURE 1 | (A) Interpretation of profile CIR-01. The interpretation is only coarse because of the low resolution of the publicly available CIR profiles (Gutscher et al., 2017). It may be worth noting that the time scale of profile CIR-01 presented by GAMB is shifted upward of $1 \mathrm{~s}$ TWT with respect to the original data; the reason for this is not explained. F1, F2 and F3 indicate the position of the faults of GAMB, though the evidence for F2 is very poor. The connection at depth of the two faults traced on the Malta Escarpment is based on the MESC profiles, where this relationship is best viewed due to their greater penetration (Argnani and Bonazzi, 2005). The arrowended line indicates the growth strata to the west of the anticline. Note the extensive erosion at sea floor. NAF, North Alfeo Fault. (B) Simplified tectonic map of the northern sector of the Malta Escarpment showing the faults mapped by (Argnani and Bonazzi, 2005) in blue and those of GAMB (F1, F2 and F3). Note the overall similarity in the fault traces. The limited extent of F2 and its position very close to F1 suggest that it is a hierarchically lower structure, though its occurrence is doubtful (see GAMB, Supplementary Figure 2). Lines with triangles: thrusts and reverse faults, lines with diamonds: anticlines. The MESC seismic grid is shown in gray, with the lines used by GAMB in dark gray. The trace of profile CIR-01 is in orange. (C) Upper panel: sketch of gravity sliding, showing the translation zone without subsidence with respect to the regional reference. Middle panel: sketch of gravity spreading that can occur in heavily sedimented margins with a mobile unit (overpressured shale or salt) at the base. Lower panel: tectonic relationships along the Malta Escarpment assuming that faulting is younger than the emplacement of the accretionary wedge, which continues to be shortened (following Argnani and Bonazzi, 2005). Panels (A,B) are after (Morley et al., 2011).

assumption that the base of units PQ2 can be dated to $650 \mathrm{kyr}$ by analogy with the age extrapolated by Camerlenghi et al. for the base of PQa is only speculative. Equally speculative is considering PQ2 as the distal equivalent of the shallow water calcarenites of the Panchina Fm. that crop out in the Hyblean Plateau. The strata of unit PQ2 are physically disconnected from the Hyblean Plateau and the seismic facies with sub-parallel, highly continuous and high amplitude reflections is indicative of a deep water turbidite system, that was likely fed from the north, along the turbidite valley of Gutscher et al., 2017.
The most critical issue, however, is the Messinian attribution to the unit MES which is taken as characterized by a high reflectivity of the top surface. GAMB describe the MES as composed of gypsum and carbonate sediments but over most of profile CIR-01 the seismic facies does not resemble the typical Messinian units (e.g., Camerlenghi et al., 2020), and often the top surface lacks a high reflectivity (GAMB, Figure 3A). In places the drawing of the top Messinian surface (S2) appears arbitary as no clear discontinuity can be seen across it and both the seismic facies and the internal stratal geometry are the same as that of the 
overlying unit (GAMB, Figure 4G). The growth strata to the west of the fold (GAMB, Figure 4G; Figure 1A) could well be of Quaternary age and resting on the deforming accretionary wedge (Figure 1C). This last interpretation (Argnani and Bonazzi 2005) is still preferable as commented below.

\section{Fault Parameters and Seismotectonic Implications: To What Extent Can We Stretch The Data?}

The seismic profiles used by GAMB in their analysis are not uniformly covering the Malta Escarpment, with a $15 \mathrm{~km}$ long gap right in the middle of the fault system (GAMB, Figure $\mathbf{5 H}$ ). The impression is that GAMB have not adopted a hierarchical approach when correlating the faults that they interpreted on seismic profiles, although only the interpretation of profile CIR01 is shown in their paper. The fault F2 interpreted in this profile is poorly convincing, and it is not present in the adjacent profile MESC-09 (Argnani and Bonazzi 2005). Regreatbly the original profiles that GAMB are supposed to use, described perhaps with overemphasis as data with unprecedented resolution, do not really contribute to define the fault pattern.

The 3D displays of the fault system (GAMB, Figures 7, 8) lack a vertical scale and it is not possible to appreciate to which depth the fault planes have been projected. The MESC profiles are the only ones that allow some inference on the deep geometry of the faults (GAMB, Supplementary Figure 2); these profiles suggest that there is only one main fault with a recent splay in its central sector (Figures 1A,B; Argnani and Bonazzi, 2005; Argnani et al., 2012).

GAMB conclude that active extension affects the northern sector of the Malta Escarpment, with fault dimension compatible with the magnitude inferred for the 1,693 earthquake. These conclusions were already stated by (Argnani and Bonazzi, 2005) and were also suggested by previous works based on less regular seismic coverage (e.g., Hirn et al., 1997). The throw analysis carried out by GAMB along the faults suffers from severe uncertainties in the stratigraphic framework and fault correlation, and therefore adds very little in term of seismotectonic implications. A single crustal fault along the Malta Escarpment bounding the half graben basin imaged by seismic data is a more realistic fault system with respect to three separate crustal faults spaced a few $\mathrm{km}$ from each other.

\section{Inferred Tectonic Evolution: Is Complication Really Necessary?}

GAMB propose a rather complicated tectonic evolution of the Malta Escarpment, with a first stage of gravity-driven tectonics during Messinian-Early Pleistocene, that affected the escarpment before the emplacement of the accretionary wedge, followed by a

\section{REFERENCES}

Argnani, A., Armigliato, A., Pagnoni, G., Zaniboni, F., Tinti, S., and Bonazzi, C. (2012). Active Tectonics along the Submarine Slope of South-Eastern Sicily and
Middle Pleistocene-to-recent extensional tectonics. According to GAMB the same faults are active during both stages; how this could be accomplished is not explained. The concept of gravitydriven tectonics adopted by GAMB is not clearly developed in the text, and the citation of a paper describing a general evolution of the Atlantic margin of Brazil (Darros de Matos, 2000) is not helping in this respect, as there is no obvious analogy to the Malta Escarpment. The overall geometry observed in seismic profile CIR-01 (GAMB, Figure 4A) does not fit with a gravity sliding, as the stratal geometry depicts a basin over the translational sector, where there should be no subsidence (Figure 1C). Gravity spreading is also unlikely because of the lack of a large sedimentary load and of a basal mobile unit (salt or overpressured shale) in the Mesozoic succession. On the other hand, mobility of Messinian salt can be ruled out, as seismic facies recalling salt are not present in this part of the Malta Escarpment. Moreover, the wavelength of both the gravity-originated basin and the extensional basin is the same, and that is against the activity of two different fault systems.

In summary, GAMB conclusions are severely undermined by stratigraphic uncertainties and poor imaging of faults at depth, and the envisaged tectonic evolution seems unnecessarily complicated. A fault system composed of one main crustal fault is simpler and more realistic. In terms of seismic hazard, large earthquakes along an individual fault are expected to have shorter recurrence time with respect to those along each fault in a system composed of three crustal faults.

\section{AUTHOR CONTRIBUTIONS}

The author confirms being the sole contributor of this work and has approved it for publication.

\section{FUNDING}

This work received financial support from the Italian Ministry of Economic Development, Directorate General for Safety-National Mining Office for Hydrocarbons and Georesources (DGS-UNMIG) under the umbrella of the offshore safety network "CLYPEA"-Innovation Network for Future Energy.

\section{ACKNOWLEDGMENTS}

I am in debt with the co-authors of my papers concerning the Ionian region, and the funding from the offshore safety network CLYPEA is gratefully acknowledged. The comments and suggestions from a reviewer and the Editor VA, in particular, have been gratefully appreciated. the Source of the 11 January 1693 Earthquake and Tsunami. Nat. Hazards Earth Syst. Sci. 12, 1311-1319. doi:10.5194/nhess-12-1311-2012

Argnani, A., and Bonazzi, C. (2005). Malta Escarpment Fault Zone Offshore Eastern Sicily: Pliocene-Quaternary Tectonic Evolution Based on New Multichannel Seismic Data. Tectonics 24, a-n. doi:10.1029/2004TC001656 
Camerlenghi, A., Del Ben, A., Hübscher, C., Forlin, E., Geletti, R., Brancatelli, G., et al. (2020). Seismic Markers of the Messinian Salinity Crisis in the Deep Ionian Basin. Basin Res. 32, 716-738. doi:10.1111/bre.12392

Darros de Matos, R. M. (2000). "Tectonic Evolution of the Equatorial South Atlantic," in Atlantic Rifts and continental Margins. Editors W. Mohriak and M. Talwani (Washington, DC: AGU Geoph. Monograph), 115, 331-354. doi:10.1029/gm115p0331

Gambino, S., Barreca, G., Gross, F., Monaco, C., Krastel, S., and Gutscher, M.-A. (2021). Deformation Pattern of the Northern Sector of the Malta Escarpment (Offshore SE Sicily, Italy): Fault Dimension, Slip Prediction, and Seismotectonic Implications. Front. Earth Sci. 8, 594176. doi:10.3389/ feart.2020.594176

Gutscher, M.-A., Kopp, H., Krastel, S., Bohrmann, G., Garlan, T., Zaragosi, S., et al. (2017). Active Tectonics of the Calabrian Subduction Revealed by New MultiBeam Bathymetric Data and High-Resolution Seismic Profiles in the Ionian Sea (Central Mediterranean). Earth Planet. Sci. Lett. 461, 61-72. doi:10.1016/ j.epsl.2016.12.020

Hirn, A., Nicolich, R., Gallart, J., Laigle, M., and Cernobori, L.ETNASEIS Scientific Group (1997). Roots of Etna Volcano in Faults of Great Earthquakes. Earth Planet. Sci. Lett. 148, 171-191. doi:10.1016/s0012-821x(97)00023-x
Morley, C. K., King, R., Hillis, R., Tingay, M., and Backe, G. (2011). Deepwater Fold and Thrust belt Classification, Tectonics, Structure and Hydrocarbon Prospectivity: A Review. Earth-Science Rev. 104, 41-91. doi:10.1016/j.earscirev.2010.09.010

Conflict of Interest: The author declares that the research was conducted in the absence of any commercial or financial relationships that could be construed as a potential conflict of interest.

Publisher's Note: All claims expressed in this article are solely those of the authors and do not necessarily represent those of their affiliated organizations, or those of the publisher, the editors and the reviewers. Any product that may be evaluated in this article, or claim that may be made by its manufacturer, is not guaranteed or endorsed by the publisher.

Copyright (C) 2021 Argnani. This is an open-access article distributed under the terms of the Creative Commons Attribution License (CC BY). The use, distribution or reproduction in other forums is permitted, provided the original author(s) and the copyright owner(s) are credited and that the original publication in this journal is cited, in accordance with accepted academic practice. No use, distribution or reproduction is permitted which does not comply with these terms. 